\title{
Analysis of the natural radioactivity concentrations of the fine dust samples in Jeju Island, Korea and the annual effective radiation dose by inhalation
}

\author{
Chung Hun Han ${ }^{1} \cdot$ Jae Woo Park ${ }^{2}$
}

Received: 30 October 2017 / Published online: 26 April 2018

(C) The Author(s) 2018

\begin{abstract}
This study analyzed the concentrations of potassium, thorium and uranium of the atmospheric $\mathrm{PM}_{10}$ aerosols which were collected at Gosan of Jeju Island during the year of 2014. The mean mass concentration of $\mathrm{PM}_{10}$ was $47.31 \mu \mathrm{g} / \mathrm{m}^{3}$. The mean radioactive concentrations of ${ }^{40} \mathrm{~K},{ }^{232} \mathrm{Th}$ and ${ }^{238} \mathrm{U}$ were $7.89,0.25$ and $0.30 \mu \mathrm{Bq} / \mathrm{m}^{3}$, respectively. The ${ }^{232} \mathrm{Th} /{ }^{238} \mathrm{U}$ activity concentration ratio of $\mathrm{PM}_{10}$ was 0.830 . The ${ }^{232} \mathrm{Th} /{ }^{238} \mathrm{U}$ ratio during Asian Dust days is 1.073 , which is higher than those in other atmospheric conditions. The concentration ratio of ${ }^{232} \mathrm{Th} /{ }^{238} \mathrm{U}$ was 0.902 in China continent.
\end{abstract}

Keywords Fine dust $\cdot \mathrm{PM}_{10} \cdot$ Natural radioactivity $\cdot$ Jeju

\section{Introduction}

Gamma radiation emitted from naturally occurring radioisotopes, such as ${ }^{40} \mathrm{~K}$ and the radionuclides from the ${ }^{232} \mathrm{Th}$ and ${ }^{238} \mathrm{U}$ series and their decay products, which exist at trace levels in all ground formations, represents the main external source of irradiation to the human body [1-3]. The human beings are exposed mainly to natural sources of radioactivity. More than $80 \%$ of the radiation dose received by mankind is due to natural radiation sources [1]. Natural radioactivity is associated mainly to primordial radionuclides, including the isotopes ${ }^{40} \mathrm{~K}$ and the progeny of the ${ }^{238} \mathrm{U}$ and ${ }^{232} \mathrm{Th}$ decay series.

The annual worldwide per caput effective radiation dose from natural source is determined by adding the various components. The annual global per caput effective dose due to natural radiation sources is $2.4 \mathrm{mSv}$. However, the range of individual doses is wide. In any large population about $65 \%$ would be expected to have annual effective

Chung Hun Han

tang007@jejunu.ac.kr

1 Institute for Nuclear Science and Technology, Jeju National University, 102 Jejudaehak-ro, Jeju 63243, Korea

2 Department of Nuclear \& Energy Engineering, Jeju National University, 102 Jejudaehak-ro, Jeju 63243, Korea doses between 1 and $3 \mathrm{mSv}$, about $25 \%$ of the population would have annual effective doses less than $1 \mathrm{mSv}$ and $10 \%$ would have annual effective doses greater than $3 \mathrm{mSv}$ [1].

Numerous studies all over the world have been conducted to determine the activity of these radioisotopes in soils and rocks to estimate the external gamma-radiation dose to the public [1]. Several studies have been conducted in the countries of the Asian continent, to determine the activity concentrations of the naturally occurring radionuclides in soil and rock samples [4-10]. In most of these studies the external radiation dose was calculated. Internal radiation dose from ingestion, tobacco and building materials were also studied [11-14]. However, internal dose due to inhalation of fine aerosol particles in the surrounded Korean peninsula are not found in the literature.

The Gosan area in Jeju Island, South Korea serves as a natural background site for characterizing the air pollution in Korean peninsula since the atmosphere in the area is relatively very little affected by artificial airborne matters. Chemical composition analyses have usually been conducted for the atmospheric aerosols collected at the site. In this study, we have measured, using the Inductively Coupled Plasma-Dynamic Reaction Cell-Mass Spectrometer (ICP-DRC-MS), radioactivity concentrations of ${ }^{40} \mathrm{~K},{ }^{232} \mathrm{Th}$ and ${ }^{238} \mathrm{U}$ contained in the atmospheric $\mathrm{PM}_{10}$ aerosols which were collected at the Gosan during the year of 2014 . 


\section{Experimental}

\section{Air sampling locations}

Air sampling for $\mathrm{PM}_{10}$ aerosols was conducted at the Gosan $\left(33^{\circ} 1^{\prime} \mathrm{N}, 126^{\circ} 10^{\prime} \mathrm{E}\right)$, which is located at the western edge of Jeju Island facing the Asian continent (Fig. 1) [15]. Jeju Island, Korea, is located at the boundary of the East China Sea and the Yellow Sea and is surrounded by mainland China, the Korean peninsula, and Japan. The Gosan sampling site is located on the hill of $72 \mathrm{~m}$ above sea level and is isolated from residential areas on the island. In order to understand physicochemical and radioactive properties of anthropogenic aerosols under Asian continental outflow, several international experiments have been conducted at the Gosan site, such as ACEAsia (Aerosol Characterization Experiment-Asia) [16] and ABC-EAREX 2005 (Atmospheric Brown Cloud-East Asia Regional Experiment 2005) [17]. To understand the link between physical and chemical properties of aerosols transported from the Asian continent and regional climate change, we need to investigate the sources and formation mechanism of secondary aerosols. In addition, contributions of local effects on the Gosan site aerosols should be qualitatively and quantitatively evaluated [18].

\section{Collection of atmospheric aerosols}

The $\mathrm{PM}_{10}$ samples have been collected using PMS-103 (APM Engineering, PMS-103, Korea), which is an automatic system with Teflon filter (Pall Corporation, ZeflourTM, $47 \mathrm{~mm} / 2.0 \mu \mathrm{m}$, USA) at $24 \mathrm{~h}$ basis with every 3 day intervals during the year of 2014. The air flow rate was kept to about $16.7 \mathrm{~L} / \mathrm{min}$, and total air flow was calculated from the flow rate and running time with MFC (mass flow controller). Quality assurance and quality control procedures were followed, including calibration of the sampler flow rates, collecting field and trip blanks, inspection and conditioning of the filter media before and after use.

\section{Sample analysis}

For obtaining accurate concentrations of the radionuclides of interest, complete digestion is required before ICP-MS. The addition of hydrofluoric acid strongly influences the recovery of the microwave acid digestion of environmental samples because it breaks down silicates and minerals better than other acid combinations [19]. However, due to the problems in glassware and torch damage of ICP-MS as well as toxicity of $\mathrm{HF}$, the acid combination $\mathrm{HNO}_{3} / \mathrm{HCl}$ was used for the digestion process [19].
The $\mathrm{PM}_{10}$ aerosols were decomposed with acids using a START D microwave digestion system (Milestone, Italy). The aerosol filters were put in a perfluoroalkoxy Teflon vessel of the microwave digestion system together with $10 \mathrm{~mL}$ acid solution $\left(5.55 \% \mathrm{HNO}_{3} / 16.75 \% \mathrm{HCl}\right)$. This vessel was heated at $180^{\circ} \mathrm{C}$ for 15 min with $1000 \mathrm{~W}$ microwave radiation to digest the $\mathrm{PM}_{10}$ aerosols. The decomposed solution was transferred through $0.45 \mu \mathrm{m}$ PVDF syringe filter (Whatman) into a $25 \mathrm{~mL}$ volumetric flask, and the volume was adjusted to $25 \mathrm{~mL}$ with $5 \mathrm{~mL}$ acid solution $\left(3 \% \mathrm{HNO}_{3} / 8 \% \mathrm{HCl}\right)$ and ultrapure water [20]. The number of elements determined by ICP-DRC-MS (Perkin Elmer, ELAN DRC-II, USA) instruments was 3 species such as ${ }^{39} \mathrm{~K},{ }^{232} \mathrm{Th}$ and ${ }^{238} \mathrm{U}$. The instrumental conditions of ICP-DRC-MS were as follows: $40 \mathrm{MHz}$ RF frequency, $1500 \mathrm{~W} \mathrm{RF}$ power, $15.0 \mathrm{~L} \mathrm{~min}^{-1}$ coolant, 0.9-1.05 $\mathrm{L} \mathrm{min}^{-1}$ Ar flow, $1.2 \mathrm{~L} \mathrm{~min}^{-1}$ auxiliary. The DRC gas was used as the ammonia. The instrumental detection limits (IDL) of ${ }^{39} \mathrm{~K},{ }^{232} \mathrm{Th}$ and ${ }^{238} \mathrm{U}$ were $27.12 \mu \mathrm{g} \mathrm{L}^{-1}, 2.11 \mathrm{ng} \mathrm{L}^{-1}$ and $2.89 \mathrm{ng} \mathrm{L}^{-1}$, respectively (Table 1).

\section{Isotope activity concentration}

Potassium, thorium and uranium were measured as trace elements in $\mathrm{PM}_{10}$ aerosol by ICP-DRC-MS. The radioactivity concentrations of the isotopes ${ }^{40} \mathrm{~K},{ }^{232} \mathrm{Th}$ and ${ }^{238} \mathrm{U}$ in the collected $\mathrm{PM}_{10}$ were calculated using the following Eq. [1] [21]:

$A_{\mathrm{i}}=\frac{\ln 2}{T_{1 / 2}} \times \frac{\rho_{\mathrm{i}} \times m_{\mathrm{e}}}{M_{\mathrm{i}}} \times N$

where $A_{\mathrm{i}}, T_{1 / 2}, \rho_{\mathrm{i}}, m_{\mathrm{e}}, M_{\mathrm{i}}$, and $N$ are the radioactivity concentration $\left(\mathrm{Bq} \mathrm{m}^{-3}\right)$, half-life time (s) of isotope $i\left({ }^{40} \mathrm{~K}\right.$ : $1.28 \times 10^{9}$ years, ${ }^{238} \mathrm{U}: 4.468 \times 10^{9}$ years, ${ }^{232} \mathrm{Th}:$ $1.405 \times 10^{10}$ years), isotopic ratio (natural abundance) of isotope $i$, the mass concentration of element e corresponding to isotope $\mathrm{i}\left(\mathrm{g} \mathrm{m}^{-3}\right)$, atomic mass $\left(\mathrm{g} \mathrm{mol}^{-1}\right)$, and the Avogadro's number $\left(6.022 \times 10^{23} \mathrm{~mol}^{-1}\right)$, respectively. The isotopic ratios for ${ }^{40} \mathrm{~K},{ }^{238} \mathrm{U}$ and ${ }^{232} \mathrm{Th}$ were $0.000117,0.99275$ and 1.0, respectively, based on the International Union of Pure and Applied Chemistry (IUPAC) report 2009 [22].

\section{Inhalation annual effective dose}

The inhalation annual effective radiation dose $\left(E_{\mathrm{i}}\right)$ due to $\mathrm{PM}_{10}$ was calculated using the following Eq. [2] [1]:

$E_{\mathrm{i}}=A_{\mathrm{i}} \times B \times d_{\mathrm{i}}\left(1-F_{0}+F_{0} F_{\mathrm{r}}\right)$

where $A_{\mathrm{i}}$ is the integrated activity concentration of radionuclide $i$ associated with $\mathrm{PM}_{10}$ in outdoor air $\left(\mathrm{Bq} \mathrm{m}^{-3}\right), B$ is the breathing rate $\left(\mathrm{m}^{3}\right.$ year $\left.^{-1}\right), d_{\mathrm{i}}$ is the 

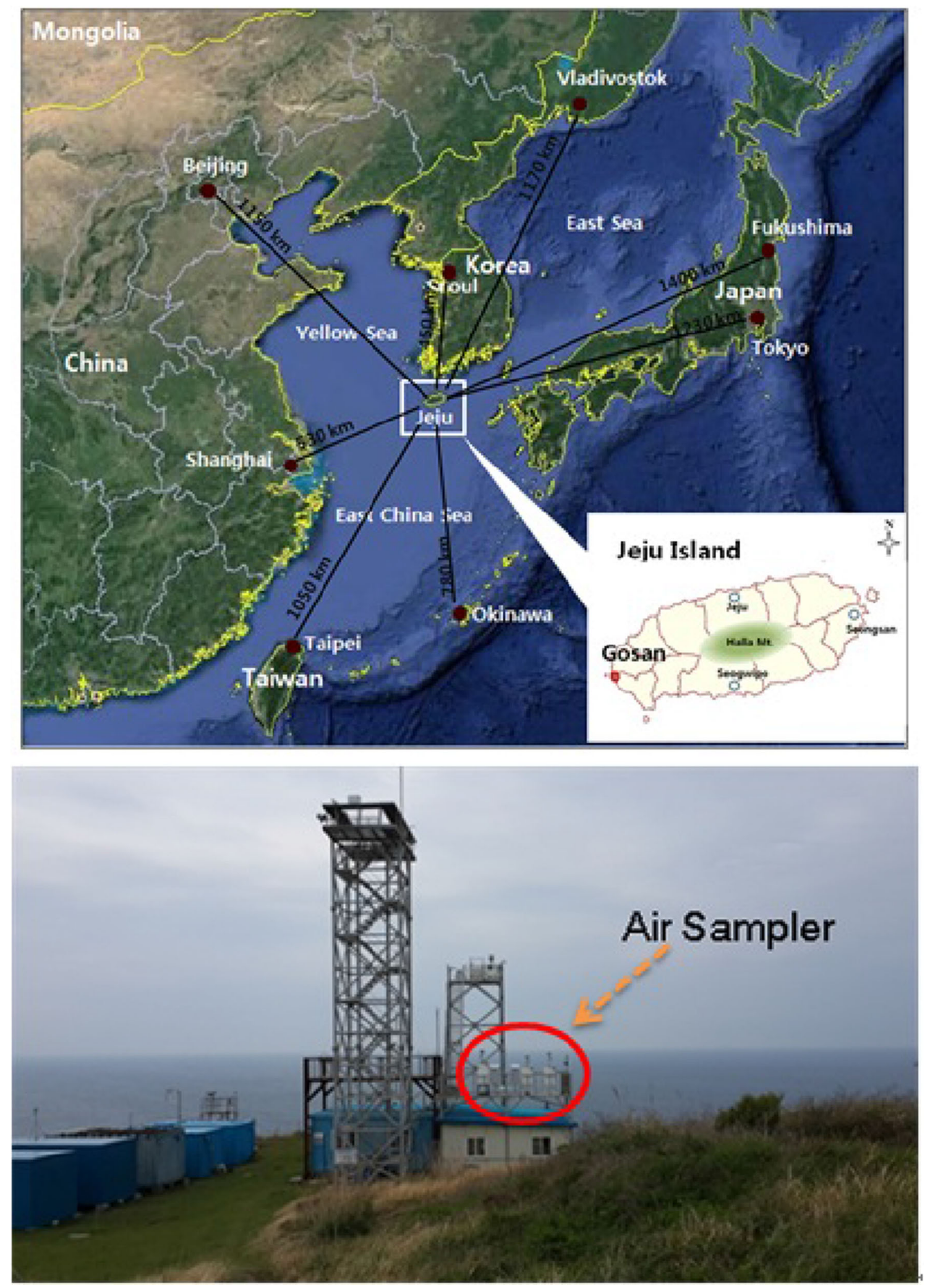

Fig. 1 Location of air sampling Gosan site in Jeju Island, Korea 
Table 1 Instrumental detection limit (IDL) and coefficient of variation $(\mathrm{CV})$ for ICP-DRC-MS $(\mathrm{n}=7)$

\begin{tabular}{lcll}
\hline Species & ${ }^{39} \mathrm{~K}\left(\mu \mathrm{g} \mathrm{L}^{-1}\right)$ & ${ }^{232} \mathrm{Th}\left(\mathrm{ng} \mathrm{L}^{-1}\right)$ & ${ }^{238} \mathrm{U}\left(\mathrm{ng} \mathrm{L}^{-1}\right)$ \\
\hline $\mathrm{IDL}$ & 27.12 & 2.11 & 2.89 \\
$\mathrm{CV}(\%)$ & 2.24 & 1.40 & 1.54 \\
\hline
\end{tabular}

committed dose per unit intake from inhalation or effective dose coefficient $\left(\mathrm{Sv} \mathrm{Bq}^{-1}\right), F_{0}$ is the indoor occupancy factor and $F_{\mathrm{r}}$ is the ratio of indoor to outdoor air concentration.

The annual effective radiation dose due to inhalation of $\mathrm{PM}_{10}$ was calculated for the six age groups identified by the International Commission on Radiological Protection (ICRP), namely 3 months, 1, 5, 10, 15 years and adults. For each of the age groups, the corresponding breathing rate and indoor occupancy factor [23], and effective dose coefficient for inhalation [24] were used. These values are summarized in Tables 2 and 3. The default modes of absorption for the isotopes were used. For the effective dose coefficient, the activity median aerodynamic diameter (AMAD) was assumed to be $1 \mu \mathrm{m}$. The ratio of indoor to outdoor air concentration $\left(F_{\mathrm{r}}\right)$ was assumed to be 0.3 $[1,25,26]$.

\section{Results and discussion}

\section{${ }^{40} \mathrm{~K},{ }^{232} \mathrm{Th}$ and ${ }^{238} \mathrm{U}$ radioactivity concentration in $\mathrm{PM}_{10}$}

As an alternative method, we have measured, using the ICP-DRC-MS, radioactivity concentrations of ${ }^{40} \mathrm{~K},{ }^{232} \mathrm{Th}$ and ${ }^{238} \mathrm{U}$ contained in the atmospheric $\mathrm{PM}_{10}$ aerosols which were collected at the Gosan during the year of 2014. A total of 115 samples have been analyzed, of which 5 samples are those collected during Asian Dust days, 47 samples collected during normal weather days (no-event days), and the remaining samples collected during the days of haze (6 samples) and fog-mist (57 samples).

The mean mass concentration of $\mathrm{PM}_{10}$ was $47.31 \mu \mathrm{g} / \mathrm{m}^{3}$. During the study period, the mean concentrations of ${ }^{40} \mathrm{~K}$, ${ }^{232} \mathrm{Th}$ and ${ }^{238} \mathrm{U}$ were $0.56,1.02$ and $0.53 \mathrm{mg} / \mathrm{kg}$-dust, respectively. Furthermore, during the study period, the activity concentrations of the radionuclides ${ }^{232} \mathrm{Th}$ and ${ }^{238} \mathrm{U}$ were $0-16.86$ (mean $4.16 \pm 2.98 \mathrm{~Bq} / \mathrm{kg}$-dust) and 0-62.07 (mean $6.48 \pm 7.43 \mathrm{~Bq} / \mathrm{kg}$-dust), respectively. They are lower than the world averages for activity concentrations of ${ }^{232} \mathrm{Th}$ and ${ }^{238} \mathrm{U}$, which are 30 and $35 \mathrm{~Bq} / \mathrm{kg}$-dust, respectively [27]. The mean active concentrations of ${ }^{40} \mathrm{~K},{ }^{232} \mathrm{Th}$ and ${ }^{238} \mathrm{U}$ during normal days are $7.89 \pm 10.89,0.25 \pm 0.37$ and $0.30 \pm$ $0.35 \mu \mathrm{Bq} / \mathrm{m}^{3}$, respectively. Furthermore, they are lower than the world averages for the mean atmospheric activity concentrations of ${ }^{232} \mathrm{Th}$ and ${ }^{238} \mathrm{U}$ associated with dust, which are 0.5 and $1.0 \mu \mathrm{Bq} / \mathrm{m}^{3}$, respectively [27]. It is worth noting that the world average is based on total suspended particulate. The low atmospheric activity concentration of ${ }^{232} \mathrm{Th}$ and ${ }^{238} \mathrm{U}$ might be attributed to the low atmospheric $\mathrm{PM}_{10}$ in Gosan site as compared to many of the world cities. The ${ }^{232} \mathrm{Th} /{ }^{238} \mathrm{U}$ activity concentration ratio of $\mathrm{PM}_{10}$ was 0.830 .

\section{Activity concentrations by atmospheric phenomenon}

The radioactivity concentrations of those isotopes were analyzed by atmospheric phenomenon (Asian Dust, Haze, FogMist and Non-Event). During Asian Dust periods (5 samples), the mean concentrations of ${ }^{40} \mathrm{~K},{ }^{232} \mathrm{Th}$ and ${ }^{238} \mathrm{U}$ were 1.24 , 2.81 and $0.87 \mathrm{mg} / \mathrm{kg}$-dust, respectively. Furthermore, during the Asian Dust period, the activity concentrations of the radionuclides ${ }^{232} \mathrm{Th}$ and ${ }^{238} \mathrm{U}$ were $7.44-16.86$ (mean $11.38 \pm 3.83 \mathrm{~Bq} / \mathrm{kg}$-dust) and 9.19-13.45 (mean $10.71 \pm$ $1.72 \mathrm{~Bq} / \mathrm{kg}$-dust), respectively. Table 4 shows also that the mean atmospheric activity concentration of ${ }^{232} \mathrm{Th}$ and ${ }^{238} \mathrm{U}$ of Asian Dust periods associated with $\mathrm{PM}_{10}$ was $1.47 \pm 0.72$ and $1.37 \pm 0.55 \mu \mathrm{Bq} / \mathrm{m}^{3}$, exceeding the revised world reference values. And these were highly as $6.94,8.57$ and 7.05 times, respectively, compared to the non-event periods (47 samples). The ${ }^{232} \mathrm{Th} /{ }^{238} \mathrm{U}$ ratio of Asian Dust was 1.073, which was higher than those of other atmospheric phenomenon (0.707-0.882) (Table 5).

\section{Inflow pathways of air mass}

We are analyzing five-day backward trajectories of the air inflow into the Gosan site using the HYSPLIT4 (HYbrid Single Particle Lagrangian Integrated Trajectory) model of National Oceanic and Atmospheric Administration (NOAA,

Table 2 Breathing rate and indoor occupancy factor values used for calculating the inhalation annual effective radiation dose due to inhalation of $\mathrm{PM}_{10}$

\begin{tabular}{|c|c|c|c|c|c|c|c|c|}
\hline \multirow[t]{2}{*}{ Age group } & \multirow[t]{2}{*}{3 months } & \multirow[t]{2}{*}{1 years } & \multirow[t]{2}{*}{5 years } & \multirow[t]{2}{*}{10 years } & \multicolumn{2}{|c|}{15 years } & \multicolumn{2}{|l|}{ Adult } \\
\hline & & & & & Male & Female & Male & Female \\
\hline Breathing rate, $B\left(\mathrm{~m}^{3}\right.$ day $\left.^{-1}\right)$ & 2.8 & 5.1 & 8.8 & 15.2 & 20.1 & 15.8 & 22.2 & 18.2 \\
\hline Indoor occupancy factor, $F_{0}$ & 1.00 & 0.96 & 0.88 & 0.88 & 0.88 & 0.92 & 0.92 & 0.92 \\
\hline
\end{tabular}


Table 3 Effective dose coefficient for inhalation $d_{\mathrm{i}}$ $\left(\mu \mathrm{Sv} \mathrm{Bq}{ }^{-1}\right)$ used for calculating the inhalation annual effective radiation dose due to inhalation of $\mathrm{PM}_{10}$

\begin{tabular}{llllllll}
\hline Nuclide & Type & 3 months & 1 years & 5 years & 10 years & 15 years & Adult \\
\hline${ }^{40} \mathrm{~K}$ & $\mathrm{~F}$ & 0.024 & 0.017 & 0.0075 & 0.0045 & 0.0025 & 0.0021 \\
${ }^{238} \mathrm{U}$ & $\mathrm{F}$ & 1.9 & 1.3 & 0.82 & 0.73 & 0.74 & 0.50 \\
& $\mathrm{M}$ & 12 & 9.4 & 5.9 & 4.0 & 3.4 & 2.9 \\
& $\mathrm{~S}$ & 29 & 25 & 16 & 10 & 8.7 & 8.0 \\
${ }^{232} \mathrm{Th}$ & $\mathrm{F}$ & 230 & 220 & 160 & 130 & 120 & 110 \\
& $\mathrm{M}$ & 83 & 81 & 63 & 50 & 47 & 45 \\
& $\mathrm{~S}$ & 54 & 50 & 37 & 26 & 25 & 25 \\
\hline
\end{tabular}

Type F: deposited materials that are readily absorbed into blood from the respiratory; type M: deposited materials that have intermediate rates of absorption into blood from the respiratory tract; type S: deposited materials that are relatively insoluble in the respiratory tract

Table 4 The associated ${ }^{40} \mathrm{~K},{ }^{238} \mathrm{U}$ and ${ }^{232} \mathrm{Th}$ concentrations of airborne $\mathrm{PM}_{10}$ by atmospheric phenomenon at Gosan site in Jeju Island, 2014

\begin{tabular}{|c|c|c|c|c|c|c|}
\hline \multirow[t]{2}{*}{ Atmospheric phenomenon } & \multicolumn{2}{|l|}{${ }^{40} \mathrm{~K}$} & \multicolumn{2}{|l|}{${ }^{232} \mathrm{Th}$} & \multicolumn{2}{|l|}{${ }^{238} \mathrm{U}$} \\
\hline & mg/kg-dust & $\mu \mathrm{Bq} / \mathrm{m}^{3}$ & $\mathrm{mg} / \mathrm{kg}$-dust & $\mu \mathrm{Bq} / \mathrm{m}^{3}$ & mg/kg-dust & $\mu \mathrm{Bq} / \mathrm{m}^{3}$ \\
\hline Asian Dust $(\mathrm{n}=5)$ & $1.24 \pm 0.64$ & $40.89 \pm 23.20$ & $2.81 \pm 0.94$ & $1.47 \pm 0.72$ & $0.87 \pm 0.14$ & $1.37 \pm 0.55$ \\
\hline Haze $(n=6)$ & $0.61 \pm 0.26$ & $18.29 \pm 17.73$ & $1.25 \pm 0.50$ & $0.50 \pm 0.40$ & $0.65 \pm 0.32$ & $0.50 \pm 0.44$ \\
\hline Fog-Mist $(\mathrm{n}=57)$ & $0.53 \pm 0.33$ & $5.58 \pm 6.24$ & $0.94 \pm 0.66$ & $0.17 \pm 0.23$ & $0.62 \pm 0.80$ & $0.24 \pm 0.24$ \\
\hline Non-Event $(\mathrm{n}=47)$ & $0.51 \pm 0.36$ & $5.85 \pm 4.67$ & $0.91 \pm 0.57$ & $0.17 \pm 0.15$ & $0.37 \pm 0.25$ & $0.19 \pm 0.16$ \\
\hline All $(n=115)$ & $0.56 \pm 0.36$ & $7.89 \pm 10.89$ & $1.03 \pm 0.73$ & $0.25 \pm 0.37$ & $0.53 \pm 0.60$ & $0.30 \pm 0.35$ \\
\hline
\end{tabular}

Table 5 The activity ratio of ${ }^{40} \mathrm{~K},{ }^{232} \mathrm{Th}$ and ${ }^{238} \mathrm{U}$ activity concentrations $\left(\mu \mathrm{Bq} / \mathrm{m}^{3}\right)$ by atmospheric phenomenon at Gosan site in Jeju Island, 2014

\begin{tabular}{llll}
\hline Atmospheric phenomenon & ${ }^{232} \mathrm{Th} /{ }^{40} \mathrm{~K}$ & ${ }^{238} \mathrm{U} /{ }^{40} \mathrm{~K}$ & ${ }^{232} \mathrm{Th} /{ }^{238} \mathrm{U}$ \\
\hline Asian Dust & 0.036 & 0.033 & 1.073 \\
Haze & 0.028 & 0.039 & 0.707 \\
Fog-Mist & 0.031 & 0.043 & 0.715 \\
Non-Event & 0.029 & 0.033 & 0.882 \\
All & 0.031 & 0.037 & 0.830 \\
\hline
\end{tabular}

USA) [28]. The frequency of air inflow into the Gosan site is $34.84 \%$ from Sector I (China continent), $22.58 \%$ from Sector II (Korean peninsula), 11.61\% from Sector III (Japan) and $5.16 \%$ from Sector IV (North Pacific Ocean) during normal days. As a result of analyzing the air volume, the concentration ratio of ${ }^{232} \mathrm{Th} /{ }^{40} \mathrm{~K}$ was 0.033 and ${ }^{238} \mathrm{U} /{ }^{40} \mathrm{~K}$ was 0.036 in Sector 1 (Table 6). The concentration ratio of ${ }^{232} \mathrm{Th} /{ }^{238} \mathrm{U}$ in this sector was measured as 0.902 . For sector $2,{ }^{238} \mathrm{U} /{ }^{40} \mathrm{~K}$ was 0.041 and ${ }^{232} \mathrm{Th} /{ }^{40} \mathrm{~K}$ was 0.031 . And ${ }^{232} \mathrm{Th} /{ }^{238} \mathrm{U}$ in this sector was measured as 0.750 . During Asian dust days, the air inflow is dominated from Sector I (Fig. 2).

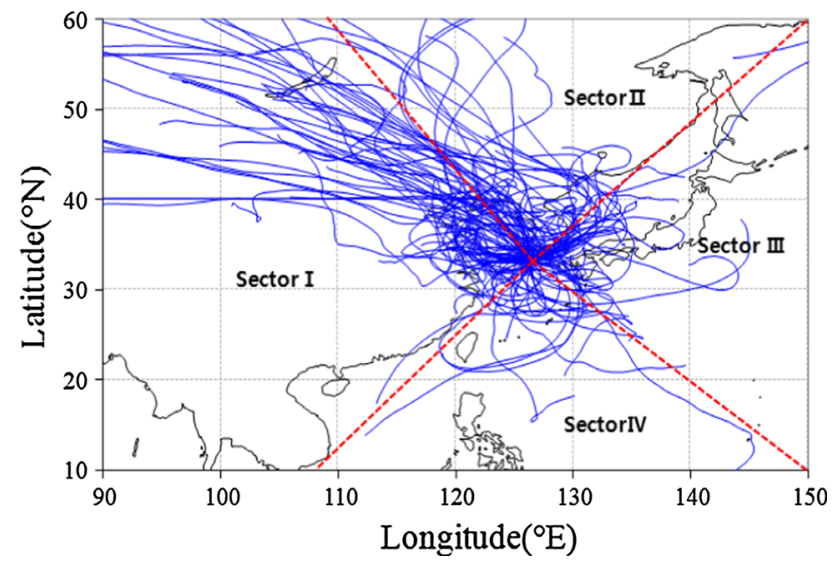

Fig. 2 5-Day backward trajectories at the Gosan Site of Jeju Island during the study period

\section{Inhalation annual effective dose}

Isotopes activity concentrations in air $\left(\mu \mathrm{Bq} / \mathrm{m}^{3}\right)$ presented in Table 4 were used in the calculation of inhalation annual effective radiation dose $\left(E_{\mathrm{i}}\right)$ to various age groups of the
Table 6 Activity concentrations and ratio of nuclides according to the sector

\begin{tabular}{lcccccc}
\hline Sector & ${ }^{40} \mathrm{~K}\left(\mu \mathrm{Bq} / \mathrm{m}^{3}\right)$ & ${ }^{232} \mathrm{Th}\left(\mu \mathrm{Bq} / \mathrm{m}^{3}\right)$ & ${ }^{238} \mathrm{U}\left(\mu \mathrm{Bq} / \mathrm{m}^{3}\right)$ & ${ }^{232} \mathrm{Th} /{ }^{40} \mathrm{~K}$ & ${ }^{238} \mathrm{U} /{ }^{40} \mathrm{~K}$ & ${ }^{232} \mathrm{Th} /{ }^{238} \mathrm{U}$ \\
\hline I & $11.38 \pm 14.24$ & $0.37 \pm 0.48$ & $0.41 \pm 0.43$ & 0.033 & 0.036 & 0.902 \\
II & $5.88 \pm 5.45$ & $0.18 \pm 0.17$ & $0.24 \pm 0.24$ & 0.031 & 0.041 & 0.750 \\
III & $4.11 \pm 4.84$ & $0.10 \pm 0.12$ & $0.14 \pm 0.15$ & 0.024 & 0.034 & 0.714 \\
IV & $2.10 \pm 1.40$ & $0.03 \pm 0.02$ & $0.09 \pm 0.16$ & 0.014 & 0.043 & 0.333 \\
\hline
\end{tabular}


Table 7 The average inhalation annual effective dose (nSv/year) to various age groups (default mode F) of the public in Gosan site from ${ }^{40} \mathrm{~K},{ }^{238} \mathrm{U}$ and ${ }^{232} \mathrm{Th}$ associated with airborne $\mathrm{PM}_{10}$

\begin{tabular}{|c|c|c|c|c|c|c|c|c|}
\hline \multirow[t]{2}{*}{ Radionuclide } & \multirow[t]{2}{*}{3 months } & \multirow[t]{2}{*}{1 years } & \multirow[t]{2}{*}{5 years } & \multirow[t]{2}{*}{10 years } & \multicolumn{2}{|c|}{15 years } & \multicolumn{2}{|l|}{ Adult } \\
\hline & & & & & Male & Female & Male & Female \\
\hline${ }^{40} \mathrm{~K}$ & 0.06 & 0.08 & 0.07 & 0.08 & 0.06 & 0.03 & 0.05 & 0.04 \\
\hline${ }^{238} \mathrm{U}$ & 0.17 & 0.24 & 0.30 & 0.46 & 0.62 & 0.45 & 0.43 & 0.35 \\
\hline${ }^{232} \mathrm{Th}$ & 17.33 & 33.01 & 48.49 & 68.05 & 83.07 & 60.54 & 77.97 & 63.92 \\
\hline Total & 17.56 & 33.32 & 48.86 & 68.59 & 83.74 & 61.02 & 78.45 & 64.31 \\
\hline
\end{tabular}

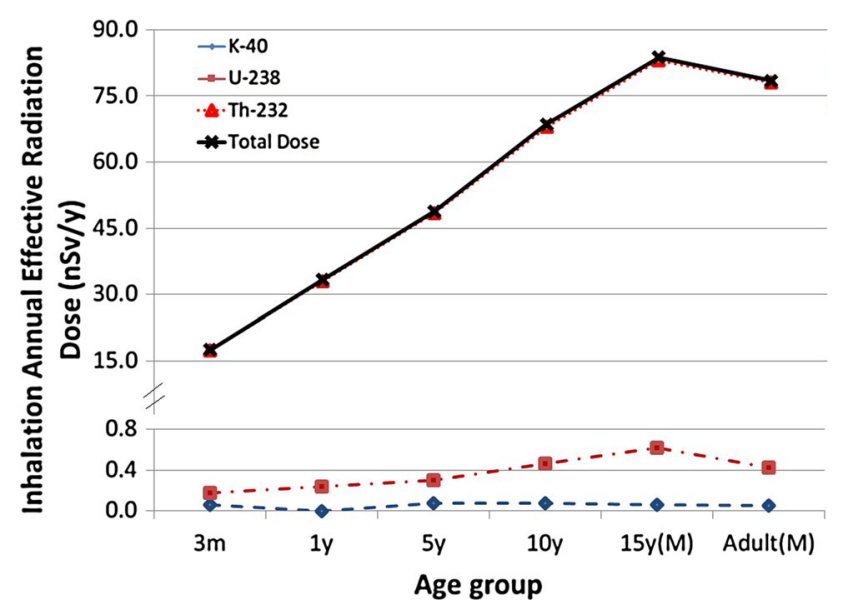

Fig. 3 Annual effective dose to various age groups in Jeju Island from inhalation ${ }^{40} \mathrm{~K},{ }^{238} \mathrm{U}$, and ${ }^{232} \mathrm{Th}$ in $\mathrm{PM}_{10}$ aerosols (F type, Male)

public. Table 7 and Fig. 3 show the results of these calculations. For instance, $E_{\text {Total }}$ was $17.56 \mathrm{nSv} /$ year to the infants ( $<1$ year), while it was $78.45 \mathrm{nSv} /$ year to the adults (male), depending on the age group. Because of the variations in air breathing rate, the total annual dose due to the natural radioactivity in airborne $\mathrm{PM}_{10}$ increases for the older age groups. These values are higher than the corresponding values calculated from the data presented in UNSCEAR 2000 [27]. It is obvious that ${ }^{232} \mathrm{Th}$ is the main contributor to the inhalation annual effective dose. ${ }^{232} \mathrm{Th}$ was found to be responsible for the total dose. On the other hand, ${ }^{40} \mathrm{~K}$ was found to slightly contribute to the total dose.

\section{Conclusions}

The atmospheric $\mathrm{PM}_{10}$ aerosols (115 samples) were collected at Gosan of Jeju Island, which is one of the natural background sites of Korea, during the year of 2014. This study analyzed using ICP-DRC-MS the concentrations of potassium, thorium and uranium, and evaluated the annual effective dose by breathing from the results. The mean mass concentration of $\mathrm{PM}_{10}$ was $47.308 \mu \mathrm{g} / \mathrm{m}^{3}$. The mean radioactive concentrations of ${ }^{40} \mathrm{~K},{ }^{232} \mathrm{Th}$ and ${ }^{238} \mathrm{U}$ were $7.89,0.25$ and $0.30 \mu \mathrm{Bq} / \mathrm{m}^{3}$, respectively. The ${ }^{232} \mathrm{Th} /{ }^{238} \mathrm{U}$ activity concentration ratio of $\mathrm{PM}_{10}$ was 0.830 . The
${ }^{232} \mathrm{Th} /{ }^{238} \mathrm{U}$ ratio during Asian Dust days is 1.073 , which is higher than those in other atmospheric conditions. During Asian Dust days, the air inflow is dominated from Sector I (China continent). The concentration ratio of ${ }^{232} \mathrm{Th} /{ }^{238} \mathrm{U}$ was 0.902 in Sector 1. In this study, the ratio of each nuclide was compared according to the inflow route. As a result, it was confirmed that the ratio of each nuclide was slightly different according to the inflow route. It is expected that this will be a preliminary data for analyzing the sources and various weather phenomena of fine dust on the peninsula. Jeju Island with less pollution source and low population density is also one of the best places as a background area in Asia. It is judged that the results become a preliminary data on the impact of fine dust from China, which has been recently intensified, on the Korean Peninsula. Therefore, it is judged as necessary to observe such Asian Dust phenomenon in the long term through collecting a large number of the $\mathrm{PM}_{10}$ aerosol filters.

Acknowledgements This research was supported by Basic Science Research Program through the National Research Foundation of Korea (NRF) funded by the Ministry of Education (No. NRF-20100020077).

Open Access This article is distributed under the terms of the Creative Commons Attribution 4.0 International License (http://creative commons.org/licenses/by/4.0/), which permits unrestricted use, distribution, and reproduction in any medium, provided you give appropriate credit to the original author(s) and the source, provide a link to the Creative Commons license, and indicate if changes were made.

\section{References}

1. United Nations Scientific Committee on Effects of Atomic Radiation (2000) Sources and Effects of Ionizing Radiation. UNSCEAR 2000 Report, vol I. United Nations, New York

2. Tzortzis M, Tsertos H (2004) Determination of thorium, uranium and potassium elemental concentrations in surface soils in Cyprus. J Environ Radioact 77:325-338

3. Al-Masri MS, Amin Y, Hassan M, Ibrahim S, Khalili HS (2006) External gamma-radiation dose to Syrian population based on the measurement of gamma-emitters in soils. J Radioanal Nucl Chem 267(2):337-343

4. Al-Kahtani SA, Farouk MA, Al-Zahrani AA (2001) Radioactivity levels in soil of three selected sites at and around Riyadh City. J Radioanal Nucl Chem 250(1):93-95 
5. Surinder S, Asha R, Rakesh KM (2005) ${ }^{226} \mathrm{Ra},{ }^{232} \mathrm{Th}$ and ${ }^{40} \mathrm{~K}$ analysis in soil samples from some areas of Punjab and Himachal Pradesh, India using gamma ray spectrometry. Radiat Meas 39:431-439

6. Kim GD, Eum CH, Bang JH (2007) Dose rate conversion factor for soil by the beta-rays and gamma-rays from ${ }^{238,235} \mathrm{U},{ }^{232} \mathrm{Th}$ and ${ }^{40}$ K. Korean Anal Sci Technol 20(6):460-467

7. Mehra R, Badhan K, Sonkawade RG, Singh Kansal S (2010) Analysis of terrestrial natural radionuclides in soil samples and assessment of avage effective dose. Ind J Pure Appl Phys 48:805-808

8. Abdul-Hadi A, Al-Qadhi W, El-Zeen E (2011) Determination of uranium, thorium and potassium contents of rock samples in Yemen. J Radioanal Nucl Chem 290:261-266

9. Al-Sulaiti H, Nasir T, AlMugren KS, Alkhomashi N, Al-Dahan N, Al-Dosari M, Bradley DA, Bukhari S, Matthews M, Regan PH, Santawamaitre T, Malain D, Habib A (2012) Determination of the natural radioactivity levels in north west of Dukhan, Qatar using high-resolution gamma-ray spectrometry. Appl Radiat Isot 70:1344-1350

10. Mehra R, Singh M (2012) Estimation of radiological risk due to concentration of ${ }^{238} \mathrm{U},{ }^{226} \mathrm{Ra},{ }^{232} \mathrm{Th}$ and ${ }^{40} \mathrm{~K}$ in soils of different geological origins in northern India. Turk J Phys 36:289-297

11. Tayyeb ZA, Kinsara AR, Farid SM (1998) A study on the radon concentrations in water in Jeddah (Saudi Arabia) and the associated health effects. J Environ Radioact 38(1):97-104

12. Kadi MW (2005) Measurement of ${ }^{238} \mathrm{U},{ }^{232} \mathrm{Th},{ }^{87} \mathrm{Rb}$, and ${ }^{40} \mathrm{~K}$ in Honey by ICP-mass spectrometry. JKAU Sci 17:197-204

13. Alharbi WR, Alzahrani JH (2012) Assessment of natural radioactivity levels and associated radiation hazards of building materials used in Saudi Arabia. J Am Sci 8(10):651-656

14. Farid SM (2012) A study on the radon concentrations in tobacco in Jeddah (SaudiArabia) and the associated health effects. Med J Islam World Acad Sci 20(3):84-93

15. Kawamura K, Watanabe T (2004) Determination of stable carbon isotopic compositions of low molecular weight dicarboxylic acids and ketocarboxylic acids in atmospheric aerosol and snow samples. Anal Chem 76:5762-5768

16. Huebert BJ, Bates T, Russell PB, Shi G, Kim YJ, Kawamura K, Carmichael G, Nakajima T (2003) An overview of ACE-Asia: strategies for quantifying the relationships between Asian aerosols and their climatic impacts. J Geophys Res 108:8633
17. Nakajima T, Yoon SC, Ramanathan V, Shi GY, Takemura T, Higurashi A, Takamura T, Aoki K, Sohn BJ, Kim SW, Tsuruta H, Sugimoto N, Shimizu A, Tanimoto H, Sawa Y, Lin NH, Lee CT, Goto D, Schutgens N (2007) Overview of the Atmospheric Brown Cloud East Asian Regional Experiment 2005 and a study of the aerosol direct radiative forcing in east Asia. J Geophys Res. https://doi.org/10.1029/2007JD009009

18. Jung J, Kawamura K (2011) Springtime carbon emission episodes at the Gosan background site revealed by total carbon, stable carbon isotopic composition, and thermal characteristics of carbonaceous particles. Atmos Chem Phys 11:10911-10928

19. Melaku S, Dams R, Moens L (2005) Determination of trace elements in agricultural soil samples by inductively coupled plasma-mass spectrometry: microwave acid digestion versus aqua regia extraction. Anal Chim Acta 543(1-2):117-123

20. Mainey A, William T (1999) Compendium of methods for the determination of inorganic compounds in ambient air (Method IO-3.1; Selection, Preparation and Extraction of Filter Material). US Environmental Protection Agency EPA/625/R-96/010a, pp 1-27

21. Magill J, Galy J (2005) Radioactivity, radionuclides, radiation. Springer, New York

22. Berglund M, Wieser ME (2011) Isotopic compositions of the elements 2009 (IUPAC Technical Report). Pure Appl Chem 83(2):397-410

23. The International Commission on Radiological Protection (2002) Basic Anatomical and physiological data for use in radiological protection: reference values. ICRP publication 89. Ann ICRP $32: 3-4$

24. The International Commission on Radiological Protection (2012) Compendium of dose coefficients based on ICRP publication 60 . ICRP publication 119. Ann ICRP 41:25-57

25. Christensen GC, Mustonen R (1987) The filtering effects of buildings on airborne particles. Radiat Prot Dosim 21:125-128

26. Roed J, Cannell R (1987) Relationship between indoor and outdoor aerosol concentration following the Chernobyl accident. Radiat Prot Dosim 21:107-110

27. United Nations Scientific Committee on Effects of Atomic Radiation (2000) Report to the general assembly. Sources and effects of ionizing radiation, vol. I. New York

28. Kim WH, Kang CH, Jung DS, Ko HJ, Lee W (2008) Compositions and pollution characteristics of total suspended particles $\left(\mathrm{PM}_{10}\right)$ at 1100 site of Mt. Halla. Anal Sci Technol 21:304-315 